\title{
A Research on the Quality Evaluation of the Innovation and Entrepreneurship Education at Chinese Universities Based on Linguistic Operators*
}

\author{
Yuan Yuan ${ }^{1}$ \\ Sichuan University \\ Jin Wang ${ }^{3}$ \\ Aviation Flight University of China
}

\author{
Huixiang Zhang ${ }^{2}$ \\ Sichuan University \\ Xiaoping $\mathrm{Li}^{4}$ \\ Sichuan University
}

\begin{abstract}
Nowadays, evaluating the quality of the innovation and entrepreneurship education at colleges and universities is a widely discussed topic in China. To address this issue, a logic hierarchy is established in this paper via the Delphi method and SPSS. It consists of four first-level indicators (i.e. the environment, resources, processes, and achievements of the innovation and entrepreneurship education), 12 second-level, and 57 third-level indicators. Then, given the advantages of the linguistic operator, especially its superiority in describing uncertain evaluation information, this paper proposes a method to evaluate the quality of the innovation and entrepreneurship education at universities based on these operators. Eventually, a case study of the S University is presented; the statistical results indicate that the proposed method has great applicability to the quality evaluation of innovation and entrepreneurship education at colleges and universities.
\end{abstract}

\section{Keywords}

Colleges and Universities • Innovation and Entrepreneurship Education • Quality Evaluation • The Linguistic Operator

\footnotetext{
* This research was supported by the Central University Basic Scientific Research Business Expenses Project of Sichuan University (sksz201603, 2018tw15, 2018XZX-02), The Research Centre for Systems Science \& Enterprise Development, Key Research of Social Sciences Base of Sichuan Province (Xq17C03).

${ }^{1}$ Business school, Sichuan University, Chengdu 610064, China. Email: yuanyuan1129@scu.edu.cn

${ }^{2}$ Business school, Sichuan University, Chengdu 610064, China. Email: 2014141084125@stu.scu.cn

${ }^{3}$ Department of Child Development, Çukurova University, Adana Turkey. Email: bsabbak@cu.edu.tr

${ }^{4}$ Correspondence to: Xiaoping Li (PhD) Business school, Sichuan University, Chengdu 610064, China. Email:

lixiaoping@scu.edu.cn
}

Citation: Yuan, Y., Zhang, H. X., Wang, J. \& Li, X. P., A Research on the Quality Evaluation of the Innovation and Entrepreneurship Education at Chinese Universities Based on Linguistic Operators. Educational Sciences: Theory \& Practice, 18(5) 1210-1223. http://dx.doi.org/10.12738/estp.2018.5.021 
There is an urgent need for the Chinese government to implement an innovation-driven development strategy and to enhance the economic efficiency. In response to this need, the reform of the innovation and entrepreneurship education at colleges and universities should be deepened, which will likewise facilitate the comprehensive reform of higher education, thereby assisting university graduates in finding better-paid employment or starting a new business. Currently, the innovation and entrepreneurship education is highlighted by the government. Establishing an effective indicator system and creating a method for evaluating the quality of the innovation and entrepreneurship education address the urgent need for facilitating the comprehensive reform of the higher education and for nurturing talents with a pioneering spirit. Meanwhile, it also meets the inevitable demands for further improving the efficiency of the allocation of educational resources and for facilitating the healthy development of the innovation and entrepreneurship education.

The research into the system and method for evaluating the quality of the innovation and entrepreneurship education at colleges and universities in China is still in its infancy. Scholars tend to investigate the necessity of this system from two perspectives: the direct and indirect impacts of the innovation and entrepreneurship education on the social and economic development, and the opportunity cost of investors and educators in the educational institutions (Romainville, 1999). Some merely establish the evaluation index system without exploring the assessment method (Betoret, \& Tomás, 2003; Coffey \& Gibbs, 2001; Denekens, 2007; Hallinger, 2010). To evaluate the effectiveness of the innovation and entrepreneurship education at universities, some scholars construct an index system based on a systematic approach, which comprises three aspects: the educational environment, inputs, and outputs. Then, the G1 method and non-linear weighted method are used to complete the index weighting and evaluation model design. Nonetheless, most of the research results do not explain the theoretical foundation and the process of the index system construction, indicating the lack of the theoretical support. The existing research results cannot be directly applied to the quality assessment of the innovation and entrepreneurship education at colleges and universities. Nevertheless, with the increasing attention paid by the government to the reform of the higher education, numerous domestic scholars have begun to investigate the quality assessment of the innovation and entrepreneurship education at colleges and universities in recent years. Maria et al., identified the quality determinants for education services provided by higher education institutions (HEIs) in Greece and measured their relative importance from the students' points of view by the multi-criteria decision-making methodology and the analytical hierarchical process (AHP) (Tsinidou, Gerogiannis, \& Fitsilis, 2010). Fouskakis, Petrakos \& Vavouras, (2016) propose a Bayesian hierarchical beta regression model to build a model for identifying, assessing and monitoring the major components of the overall teaching quality. The above methods cannot be directly used to evaluate the quality of the innovation and entrepreneurship education at colleges and universities, since they have either a weak scientific index system or a simple calculation, or these approaches are not empirically tested.

In light of the evaluation indicator of the innovation and entrepreneurship education at colleges and universities, there are more qualitative indexes but less quantitative indexes. How to translate the qualitative indexes into the quantitative indexes effectively is the key to realize the accurate evaluation. The linguistic operators may better and more completely describe the uncertainty of the decision-makers' evaluation of the reality. Therefore, in the context of the quality evaluation of the innovation and entrepreneurship education in China, based on the existing literature, this paper first establishes the evaluation system of the innovation and 
entrepreneurship education based on the CIPP education evaluation model. Secondly, combining the characteristics of the linguistic operators, it presents an evaluation method. Finally, through a case study, the application process of this evaluation approach is demonstrated, and its operability and practicability are proved.

\section{Establishing an indicator system for evaluating the quality of the innovation and entrepreneurship education at colleges and universities}

\section{Establishing the indicator system}

Evaluating the quality of the innovation and entrepreneurship education at universities significantly impacts both the internal evaluation of the education effectiveness (i.e. the universities' own evaluation of their education effectiveness) and the external supervision and management. The existing research results, however, indicate that there is a lack scientific and reasonable theoretical basis in the construction of the evaluation index system. Moreover, an indicator system that can fully reflect the characteristics of the innovation and entrepreneurship education at colleges and universities is not established; the basic factors for evaluating the innovation and entrepreneurship education proposed by the State Council in "Opinions on Implementation" are not examined. Therefore, the paper constructs an index system via two steps, as follows.

First, the preliminary indicator system is formulated. It is based on the theoretical model of the CIPP education evaluation put forward by Stufflebeam $(2001 ; 2003 ; 2007 ; 2017)$, a well-known American educational evaluation scholar. The CIPP model emphasizes decision orientation, process orientation, and improvement orientation and has been widely used in the research into assessing the educational development in various countries. Then, the paper takes into consideration the basic requirements for and specific tasks of reforming the innovation and entrepreneurship education at colleges and universities mentioned in the "Opinions on Implementation" and other scholars' index systems of assessing the entrepreneurship education (Jiang, 2015; Gao and Hua, 2015; Liu, 2016; Feng and Tong, 2013; Feng \& Tong, 2013; Xu \& Bai, 2014; Liu, Zhang and Zhang, 2009; Xie \& Liu, 2010). Eventually, a preliminary indicator system with four first-level, 12 secondlevel and 38 three-level indicators regarding this issue is constructed according to the principles of operability, comprehensiveness, openness, development, rationality, and systematicness.

Second, the final evaluation indicators are selected. The Delphi method is a group decision-making method characterized by the feedback, anonymity and statistical estimation. It is especially suitable for analyzing and predicting information without substantial historical data and information which may be easily influenced by related factors (Dalkey \& Helmer, 1963; Okoli \& Pawlowski, 2004). In this study, 20 experts (scholars, fulltime teachers and managers) engaged in the innovation and entrepreneurship education is invited to conduct four repeated rounds of activities; they then provide consultation and feedback. 62 valid consultation questionnaires are gathered. Through screening and supplementing the preliminary proposed index system, the paper finally determines the framework and specific indicators. For instance, the second-level indicator entitled "cultural atmosphere" is deleted, and that named "top design" is changed to "school environment"; likewise, some of the third-level indicators are merged, deleted, and adjusted. In addition, a statistical analysis is conducted to examine the collected data. Then, the paper proceeds to calculate the experts' authority, the 
Yuan, Zhang, Wang, Li / A Research on the Quality Evaluation of the Innovation and Entrepreneurship Education at...

coefficient of the expert coordination and the variation coefficient of the evaluation results, through many rounds of consultation, feedback, modification, and adjustment. The final statistics show that the variation coefficient of each indicator is lower than 0.2 , indicating that the experts reach a consensus on the selection of the indicators. The paper ultimately establishes a system evaluating the quality of the innovation and entrepreneurship education at universities with four first-level, 12 second-level, and 57 third-level indicators (See Table 1).

Table 1

An Indicator System Assessing the Quality of the Innovation and Entrepreneurship Education at Universities

\begin{tabular}{|c|c|c|}
\hline First-level indicators & $\begin{array}{l}\text { Second-level } \\
\text { indicators }\end{array}$ & Third-level indicators \\
\hline \multirow{8}{*}{$\begin{array}{l}\text { Context evaluation (C) } \\
\text { Environment of the } \\
\text { innovation } \\
\text { entrepreneurship education }\end{array}$} & \multirow{4}{*}{$\begin{array}{l}\text { External } \\
\text { environment }\end{array}$} & $\begin{array}{l}\text { The policy support for the innovation and entrepreneurship } \\
\text { education in the region }\end{array}$ \\
\hline & & $\begin{array}{l}\text { The development level of the service system facilitating the } \\
\text { innovation and entrepreneurship in the region }\end{array}$ \\
\hline & & $\begin{array}{l}\begin{array}{l}\text { The guidance of public opinion about innovation and } \\
\text { entrepreneurship in the region }\end{array} \\
\end{array}$ \\
\hline & & $\begin{array}{l}\text { The incentive mechanism for reforming the talent management in } \\
\text { the region }\end{array}$ \\
\hline & \multirow{4}{*}{ School environment } & $\begin{array}{l}\text { Innovative and entrepreneurial education included into the } \\
\text { strategic development plan of the universities }\end{array}$ \\
\hline & & $\begin{array}{l}\text { Improve the innovation and entrepreneurship education system of } \\
\text { the universities }\end{array}$ \\
\hline & & $\begin{array}{l}\text { Formulate and implement the innovation and entrepreneurship } \\
\text { reform plan at the universities }\end{array}$ \\
\hline & & $\begin{array}{l}\text { Combine the advanced concept of pioneering education to optimize } \\
\text { the talent training system }\end{array}$ \\
\hline \multirow{14}{*}{$\begin{array}{l}\text { Input evaluation (I) } \\
\text { Resources of the innovation } \\
\text { and entrepreneurship } \\
\text { education }\end{array}$} & \multirow{5}{*}{ Faculty training } & $\begin{array}{l}\text { Establish a full-time teacher team providing the innovative } \\
\text { entrepreneurship education and career guidance }\end{array}$ \\
\hline & & $\begin{array}{l}\text { Employ talents in all walks of life, for example, well-known } \\
\text { scientists, successful entrepreneurs, and venture capitalists to teach } \\
\text { the innovation and entrepreneurship courses }\end{array}$ \\
\hline & & $\begin{array}{l}\text { Incorporate the concept of innovation and entrepreneurship } \\
\text { education into the initial teaching training, curriculum rotation } \\
\text { training, and core member training }\end{array}$ \\
\hline & & $\begin{array}{l}\text { Establish a system allowing relevant professionals and full-time } \\
\text { teachers to be on secondment in factories and enterprises to obtain } \\
\text { experience }\end{array}$ \\
\hline & & $\begin{array}{l}\text { Improve the benefit distribution mechanism for scientific and } \\
\text { technological achievements at universities }\end{array}$ \\
\hline & \multirow{5}{*}{ Guiding service } & $\begin{array}{l}\text { Set up a leading group on the innovation and entrepreneurship at } \\
\text { universities }\end{array}$ \\
\hline & & $\begin{array}{lllll}\begin{array}{l}\text { Establish a special institution offering innovation } \\
\text { entrepreneurship guidance and service }\end{array} & & \\
\end{array}$ \\
\hline & & Provide a unique base or place for innovation and entrepreneurship \\
\hline & & $\begin{array}{l}\text { Improve the continuous information service system of innovation } \\
\text { and entrepreneurship }\end{array}$ \\
\hline & & $\begin{array}{l}\text { Implement policies regarding university students' innovative } \\
\text { training }\end{array}$ \\
\hline & \multirow{4}{*}{ Financial support } & Special support funds from the government finance \\
\hline & & Special support funds from universities \\
\hline & & Support funds from the corporate sponsorship \\
\hline & & Support from the public funding \\
\hline \multirow{3}{*}{$\begin{array}{l}\text { Processes of the innovation } \\
\text { and entrepreneurship } \\
\text { education }\end{array}$} & \multirow{3}{*}{ Talent cultivation } & $\begin{array}{l}\text { Establish a demand-oriented discipline structure and an } \\
\text { employment- and entrepreneurship- oriented talent training } \\
\text { adjustment mechanism }\end{array}$ \\
\hline & & $\begin{array}{l}\text { Facilitate cooperation and exchange between different universities, } \\
\text { universities and enterprises, universities and local governments, } \\
\text { universities and research institutions, and universities and other } \\
\text { international organizations }\end{array}$ \\
\hline & & $\begin{array}{l}\text { Set up a cross-departmental, interdisciplinary and trans- } \\
\text { disciplinary training mechanism }\end{array}$ \\
\hline
\end{tabular}


Yuan, Zhang, Wang, Li / A Research on the Quality Evaluation of the Innovation and Entrepreneurship Education at...

\begin{tabular}{|c|c|c|}
\hline & & Develop interdisciplinary cross-curricular courses \\
\hline & & $\begin{array}{l}\text { Attract the input of social resources and high quality foreign } \\
\text { resources }\end{array}$ \\
\hline & & $\begin{array}{l}\text { Facilitate the integration of professional education and innovation } \\
\text { and entrepreneurship education }\end{array}$ \\
\hline & & $\begin{array}{l}\text { Create a qq group regarding the curriculum of innovation and } \\
\text { entrepreneurship education }\end{array}$ \\
\hline & Curriculum system & $\begin{array}{l}\text { Develop an information network about the high quality } \\
\text { curriculums of innovation and entrepreneurship education }\end{array}$ \\
\hline & & Open an online course learning and credit recognition system \\
\hline & & $\begin{array}{l}\text { Invite excellent talents in academia and various industries to write } \\
\text { key textbooks on innovation and entrepreneurship education }\end{array}$ \\
\hline & & $\begin{array}{l}\text { Build a center for entrepreneurship experiments, practice, and } \\
\text { training }\end{array}$ \\
\hline & & $\begin{array}{l}\text { Open to all students the science and technology innovation } \\
\text { resources }\end{array}$ \\
\hline & & $\begin{array}{l}\text { Build the science park, innovation and "incubation" parks at } \\
\text { universities }\end{array}$ \\
\hline & Practice and training & $\begin{array}{l}\text { Construct for college students the off-campus practice base, } \\
\text { venture demonstration base, as well as the science and technology } \\
\text { experiment base }\end{array}$ \\
\hline & & $\begin{array}{l}\text { Implement the projects regarding students' innovation and } \\
\text { entrepreneurship training }\end{array}$ \\
\hline & & $\begin{array}{l}\text { Encourage students to participate in the national innovation and } \\
\text { entrepreneurship competition }\end{array}$ \\
\hline & & $\begin{array}{l}\text { Support students to set up innovation and entrepreneurship } \\
\text { associations and clubs }\end{array}$ \\
\hline & & Hold lectures and forums on innovation and entrepreneurship \\
\hline & & $\begin{array}{l}\text { Establish a credit accumulation, approval and transfer system of } \\
\text { innovation and entrepreneurship education }\end{array}$ \\
\hline & Teaching & $\begin{array}{l}\text { Develop a training program on facilitating students' innovative and } \\
\text { entrepreneurial ability }\end{array}$ \\
\hline & & $\begin{array}{l}\text { Formulate a teaching and examination system that conforms to the } \\
\text { philosophy of innovation and entrepreneurship education }\end{array}$ \\
\hline & & Introduce related regulations on the flexible schooling system \\
\hline & & Establish scholarships on innovation and entrepreneurship \\
\hline & & The percentage of students who start a business \\
\hline & The quality of the & The proportion of students' invention patents \\
\hline & & Awards for students in innovation and entrepreneurship contests \\
\hline & & $\begin{array}{l}\text { the number of the enterprises being incubated at the science park at } \\
\text { universities }\end{array}$ \\
\hline Product evaluation $(\mathrm{P})$ & $\begin{array}{l}\text { Scientific } \\
\text { technological }\end{array}$ & $\begin{array}{l}\text { The quantity of the enterprises successfully incubated from the } \\
\text { science park at universities }\end{array}$ \\
\hline Achievements & & The number of authorized invention patents \\
\hline innovation and & & The quantity of signed contracts on technology transfer \\
\hline entrepreneurship education & & The influence of innovational education on the public opinions \\
\hline & & Social recognition of innovation and entrepreneurship education \\
\hline & Social benefits & Employment rate \\
\hline & & Entrepreneurship rate \\
\hline & & Visibility of the outstanding entrepreneurial alumni \\
\hline
\end{tabular}

\section{Description of the indicator system}

Based on the CIPP model, the evaluation index system of the innovation and entrepreneurship education at colleges and universities is a combination of context, input, process, and product assessment. Likewise, this system combines process evaluation with result evaluation and the subjective evaluation with objective evaluation. It consists of four evaluation dimensions: the environment, resources, process, and achievements of the innovation and entrepreneurship education. 
The context (C) (i.e. the educational environment of innovation and entrepreneurship), which comprises both the school and external environment, is the precondition for the innovation and entrepreneurship education at colleges and universities. The external environment principally refers to the management system and action plans formulated by the government in the region where the university is located. These plans will facilitate the innovation and entrepreneurship education in terms of policy support, service support, guidance of public opinions, and the talent management. The school environment mainly means the ideological and cultural measures taken by the colleges and universities. Input (i.e. innovation and entrepreneurship education resources) refers to the human resources, financial resources, and organizational resources regarding the innovation and entrepreneurship education. It is the guarantee of the innovation and entrepreneurship education at colleges and universities. Human resources, namely the training of the teachers, refer to the investment in faculty training regarding the innovation and entrepreneurship education at colleges and universities. Financial resources refer to the financial support, for instance, funds provided by the government, universities themselves, enterprises, and the public to facilitate the innovation and entrepreneurship education. Organizational resources mainly mean the guidance and service about the innovation and entrepreneurship education provided by the colleges and universities. Process (P) (i.e. the process of the innovation and entrepreneurship education), which consists of personnel training, curriculum system, practice and training (for students) and teaching management, is the core of the innovation and entrepreneurship education at colleges and universities. Talent cultivation mainly means the demand-oriented course structure and the novel (employment- and entrepreneurship- oriented) adjustment mechanism for talent training at colleges and universities. The curriculum system principally refers to the adjustment of the curriculum based on the innovation and entrepreneurship education requirements. Practice and training refer to the educational facilities and practice bases provided by the university. Teaching management is the teaching and grade management system set up by colleges and universities to ensure the orderly progress of the innovation and entrepreneurship education. Product (P) (i.e. the outcome of the innovation and entrepreneurship education) refers to the achievement of the goal and the social influence, comprising the quality of students, achievements in science and technology, and social benefits. The quality of students is the manifestation of the innovation and entrepreneurship education at the student level. The achievement of science and technology is the manifestation of the innovation and entrepreneurship education at the school level. The social benefits are the embodiment of the innovation and entrepreneurship education at the social level.

\section{The evaluation of the quality of the innovation and entrepreneurship at universities based on linguistic operators}

There are numerous methods for quality evaluation, such as the principal component analysis, the analytic hierarchy process, the gray relational analysis, and the data envelopment analysis. These methods are principally applied in certain fields. For instance, the principal component analysis is mainly used to deal with the closer correlation of the indicators. The advantage of AHP lies in resolving the problem of data evacuation. The gray relational analysis largely deals with the multi-factor and nonlinear problems in the statistical analysis. The data envelopment analysis is mostly used in the input-output model. Nevertheless, there are few approaches to the 
quality evaluation of the innovation and entrepreneurship at universities due to its characteristics such as subjective information and ambiguous indicators. Therefore, transforming subjective information is most crucial in the process of evaluation. The accuracy and convenience of the linguistic operator in information conversion enable it to effectively deal with a host of fuzzy evaluation scenarios. Hence, the linguistic operator is suitable for evaluating the quality of the innovation and entrepreneurship at colleges and universities. Therefore, the linguistic operator is used as the research method in this paper.

\section{The linguistic operator theory}

Linguistic variables. Linguistic variables refer to the variables that quantify the natural language. Linguistic variables are based on the semantic model, the value of which lies not in numbers but in the vague words or sentences, such as "relatively" and "slightly". For example, the set \{very poor, poor, relatively poor, fair, a little good, good, and very good \} can be used to evaluate the quality of an item. Linguistic variables are used in the calculation of the vague words.

Definition 1 (Aggarwal, 2017; Xu, Merigó, \& Wang, 2012) Let $L$ be a finite discrete set, satisfying

$$
L=\left\{l_{j} \mid j=-t,-(t-1), \cdots, 0, \cdots, t-1, t\right\}\left(t \in Z^{*} \text { and } t \geq 1\right) .
$$

$l_{j}$ is the linguistic variable. $-t$ and $t$ represent the lower and upper limit of those linguistic variables, respectively. Accordingly, the quality evaluation set above can be expressed as $L=\left\{l_{-3}, l_{-2}, l_{-1}, l_{0}, l_{1}, l_{2}, l_{3}\right\}$.

$L$ is discrete; hence, certain linguistic information is likely to be lost in aggregation. To avoid this situation, $L$ is extended into a continuous set $\bar{L}=\left\{\bar{l}_{\alpha}=-(t+1)<\alpha<t+1, \alpha \in R\right\}\left(t \in Z^{*}\right.$ and $\left.t \geq 1\right), L \subset \bar{L}$.

Definition 2 (Wu and Chen, 2007) Operation of the linguistic variables

Let $(x)=\tan \frac{\pi x}{2 t+2}, x \in(-t-1, t+1)$. If $\forall \bar{l}_{\alpha}, \bar{l}_{\beta} \in \bar{L}, \lambda \in R$, then,

(1) $\bar{l}_{\alpha} \oplus \bar{l}_{\beta}=\bar{l}_{f^{-1}(f(\alpha)+f(\beta))}$,

(2) $\bar{l}_{\alpha} \otimes \bar{l}_{\beta}=\bar{l}_{f^{-1}(f(\alpha) \cdot f(\beta))}$,

(3) $\lambda \bar{l}_{\alpha}=\bar{l}_{f^{-1}(\lambda f(\alpha))}$.

Where $f^{-1}(x)=\frac{(2 t+2) \arctan (x)}{\pi}$ is a monotonic continuous function which satisfies

(1) $\lim _{x \rightarrow-\infty} f^{-1}(x)=-t-1$,

(2) $\lim _{x \rightarrow+\infty} f^{-1}(x)=t+1$,

(3) $f^{-1}(0)=0$.

Then, the mean and variance of the linguistic vector made up of linguistic variables are as follows:

Definition 3 (He, Guo, Jin \& Ren, 2016) Let the linguistic vector be $\bar{l}_{\alpha}=\left(\bar{l}_{\alpha_{1}}, \bar{l}_{\alpha_{2}}, \cdots, \bar{l}_{\alpha_{n}}\right)^{T}, \bar{l}_{\alpha_{i}} \in \bar{L}(i=$ $1,2, \cdots, n)$, then,
(1) $E\left(\bar{l}_{\alpha}\right)=\bar{l}_{\bar{\alpha}}=\bar{l}_{f^{-1}\left(\frac{1}{n} \Sigma_{i=1}^{n} f\left(\alpha_{i}\right)\right)}$,
(2) $D\left(\bar{l}_{\alpha}\right)=\frac{1}{n} \sum_{i=1}^{n}\left(f\left(\alpha_{i}\right)-\frac{1}{n} \sum_{i=1}^{n} f\left(\alpha_{i}\right)\right)^{2}$. 
Linguistic weighted arithmetic average (LWAA) operators. The weighted average method is often adopted in language information aggregation. The linguistic weighted arithmetic average (LWAA) operator is defined based on the related concepts and calculation of the linguistic operators and weighted average operators.

Definition 4 (Hu, Ren, Jin, Lan \& Luo, 2013) Let $\left\{l_{\beta_{1}}, l_{\beta_{2}}, \cdots l_{\beta_{n}}\right\}$ be the linguistic variable set to be aggregated. As for the mapping $L W A A: \bar{L}^{n} \rightarrow \bar{L}$, if

$$
\begin{aligned}
\operatorname{LWAA}\left(\bar{l}_{\beta_{1}}, \bar{l}_{\beta_{2}}, \ldots,\right. & \left.\bar{l}_{\beta_{n}}\right)=\omega_{1} \bar{l}_{\beta_{1}} \oplus \omega_{2} \bar{l}_{\beta_{2}} \oplus \ldots \oplus \omega_{n} \bar{l}_{\beta_{n}} \\
& =\bar{l}_{f^{-1}\left[\omega_{1} f\left(\beta_{1}\right)+\omega_{2} f\left(\beta_{2}\right)+\cdots+\omega_{n} f\left(\beta_{n}\right)\right]} \\
& =\bar{l}_{f^{-1}\left[\Sigma_{j=1}^{n} \omega_{j} f\left(\beta_{j}\right)\right]}
\end{aligned}
$$

where $W=\left(\omega_{1}, \omega_{2}, \ldots, \omega_{n}\right)^{T}$ is the corresponding weight vector, satisfying $\omega_{j} \geq 0(j=1,2, \ldots, n)$, $\sum_{j=1}^{n} \omega_{j}=1$. Hence, LWAA represents the linguistic weighted arithmetic average operator.

If all linguistic variables in the set have the same weight, then:

$$
\begin{aligned}
\operatorname{LAA}\left(\bar{l}_{\beta_{1}}, \bar{l}_{\beta_{2}}, \ldots, \bar{l}_{\beta_{n}}\right) & =\frac{1}{n} \bar{l}_{\beta_{1}} \oplus \frac{1}{n} \bar{l}_{\beta_{2}} \oplus \ldots \oplus \frac{1}{n} \bar{l}_{\beta_{n}} \\
& =\frac{1}{n}\left(\bar{l}_{\beta_{1}} \oplus \bar{l}_{\beta_{2}} \oplus \ldots \oplus \bar{l}_{\beta_{n}}\right) \\
& =\frac{1}{n} \bar{l}_{f^{-1}\left[\Sigma_{j=1}^{n} f\left(\beta_{j}\right)\right]}
\end{aligned}
$$

The quality evaluation model of the innovation and entrepreneurship at universities based on linguistic operators

$\mathrm{N}$ evaluators evaluate the $\mathrm{m}$ indicators, obtaining the linguistic information and the corresponding matrix $\bar{L}=\left(\bar{l}_{\alpha_{i j}}\right)_{n \times m}=\left(\bar{l}_{\alpha_{1}}, \bar{l}_{\alpha_{2}}, \cdots, \bar{l}_{\alpha_{m}}\right)$.

(1) Determine the score of each indicator

According to the definition 3 , the score of the $j_{t h}$ indicator is

$E\left(\bar{l}_{\alpha_{j}}\right)=\bar{l}_{\bar{\alpha}_{j}}=\bar{l}_{f^{-1}\left(\frac{1}{n} \sum_{i=1}^{n} f\left(\alpha_{j}\right)\right), j=1,2, \cdots, m}$.

(2) Determine the weight of each indicator

To some extent, the degree of variation of an indicator may reflect its importance. That is, the greater the degree of variation of the indicator, the greater the amount of information provided and the greater its weight should be. Therefore, this paper uses the standard deviation to determine the weight of each indicator.

First, according to the definition 3 , the standard deviation of the $j_{t h}$ indicator is

$$
\sigma\left(\bar{l}_{\alpha_{j}}\right)=\sqrt{D\left(\bar{l}_{\alpha_{j}}\right)}=\sqrt{\frac{1}{n} \sum_{i=1}^{n}\left(f\left(\alpha_{i j}\right)-f\left(\bar{\alpha}_{j}\right)\right)^{2}}, j=1,2, \cdots, m .
$$

Next, the weight of the $j_{t h}$ indicator is expressed as:

$\omega_{j}=\frac{\sigma\left(\bar{l}_{\alpha_{j}}\right)}{\sum_{j=1}^{n} \sigma\left(\bar{l}_{\alpha_{j}}\right)}, j=1,2, \cdots m$.

(3) Determine the overall evaluation score

According to the definition 4, the overall evaluation score is calculated as: 


$$
\bar{l}_{\beta}=\omega_{1} \bar{l}_{\bar{\alpha}_{1}} \oplus \omega_{2} \bar{l}_{\bar{\alpha}_{2}} \oplus \ldots \oplus \omega_{n} \bar{l}_{\bar{\alpha}_{n}}=\bar{l}_{f^{-1}\left[\sum_{j=1}^{n} \omega_{j} f\left(\bar{\alpha}_{j}\right)\right] .}
$$

(4) The steps evaluate the quality of the innovation and entrepreneurship education at universities based on linguistic operators:

Step1: Each evaluator scores the indicators, obtaining the linguistic information matrix $\bar{L}=\left(\bar{l}_{\alpha_{i j}}\right)_{n \times m}$,

Step2: The score of each indicator is obtained via the equation (1),

Step3: The weight of each indicator is obtained via the equation (2) and (3),

Step4: The overall evaluation score is obtained via the equation (4).

\section{Empirical research}

The S University is one of China's top universities directly under the Ministry of Education and a comprehensive research-oriented university in western China as well. This university fully implements the State Council's Opinions on Deepening the Reform of the Innovation and Entrepreneurship Education at Colleges and Universities and the eighteen reform plans regarding this issue. It seeks to incorporate the innovation and entrepreneurship education into the entire process of both school development and personnel training. Through updating concepts and highlighting reform and innovation, the S University strives to cultivate high-quality talents with innovation and entrepreneurship needed by the country and the times. It will develop into a worldclass innovation and entrepreneurship university by 2025. Currently, the S University has made some achievements in the innovation and entrepreneurship education through taking certain measures. In recent years, this university has implemented the "small-class, interactive, non-standard and whole process" teaching reform, thereby enhancing students' ability of independent and critical thinking. Moreover, for the sixth consecutive years, the "University Immersion Program" has been implemented to improve students' international competitiveness. The S University creates a platform named "I Innovation Street" to cultivate students' ability of innovation and entrepreneurship. Likewise, it highlights the construction of five platforms, namely the "double" education and practice platform, platform for innovation and creativity, transformative technology research and development platform, platform incubating high-tech enterprises, and the "One Belt One Road" innovation and entrepreneurship platform.

Step1: The score of each indicator is obtained via equation (1), as illustrated in Table 2.

Table 2

The Score of 57 Indicators

\begin{tabular}{|c|c|c|c|c|c|c|c|c|c|}
\hline $\mathrm{E}\left(\overline{\mathrm{l}}_{\alpha_{1}}\right)$ & $\mathrm{E}\left(\overline{\mathrm{l}}_{\alpha_{2}}\right)$ & $\mathrm{E}\left(\overline{\mathrm{l}}_{\alpha_{3}}\right)$ & $\mathrm{E}\left(\overline{\mathrm{l}}_{\alpha_{4}}\right)$ & $\mathrm{E}\left(\overline{\mathrm{l}}_{\alpha_{5}}\right)$ & $\mathrm{E}\left(\overline{\mathrm{l}}_{\alpha_{6}}\right)$ & $\mathrm{E}\left(\overline{\mathrm{l}}_{\alpha_{7}}\right)$ & $\mathrm{E}\left(\overline{\mathrm{l}}_{\alpha_{8}}\right)$ & $\mathrm{E}\left(\overline{\mathrm{l}}_{\alpha_{9}}\right)$ & $\mathrm{E}\left(\overline{\mathrm{l}}_{\alpha_{10}}\right)$ \\
\hline 1.079 & 1.005 & 1.018 & 1.151 & 1.122 & 1.049 & 1.222 & 1.049 & 0.088 & 0.051 \\
\hline $\mathrm{E}\left(\overline{\mathrm{l}}_{\alpha_{11}}\right)$ & $\mathrm{E}\left(\overline{\mathrm{l}}_{\alpha_{12}}\right)$ & $\mathrm{E}\left(\overline{\mathrm{l}}_{\alpha_{13}}\right)$ & $\mathrm{E}\left(\overline{\mathrm{I}}_{\alpha_{14}}\right)$ & $\mathrm{E}\left(\overline{\mathrm{l}}_{\alpha_{15}}\right)$ & $\mathrm{E}\left(\overline{\mathrm{I}}_{\alpha_{16}}\right)$ & $\mathrm{E}\left(\overline{\mathrm{l}}_{\alpha_{17}}\right)$ & $\mathrm{E}\left(\mathrm{l}_{\alpha_{18}}\right)$ & $\mathrm{E}\left(\overline{\mathrm{l}}_{\alpha_{19}}\right)$ & $\mathrm{E}\left(\overline{\mathrm{l}}_{\alpha_{20}}\right)$ \\
\hline 0.036 & 0.124 & 0.000 & 1.409 & 0.088 & 1.383 & 0.706 & 0.176 & 1.250 & 1.409 \\
\hline $\mathrm{E}\left(\overline{\mathrm{l}}_{\alpha_{21}}\right)$ & $\mathrm{E}\left(\overline{\mathrm{l}}_{\alpha_{22}}\right)$ & $\mathrm{E}\left(\overline{\mathrm{l}}_{\alpha_{23}}\right)$ & $\mathrm{E}\left(\overline{\mathrm{l}}_{\alpha_{24}}\right)$ & $\mathrm{E}\left(\overline{\mathrm{I}}_{\alpha_{25}}\right)$ & $\mathrm{E}\left(\overline{\mathrm{I}}_{\alpha_{26}}\right)$ & $\mathrm{E}\left(\overline{\mathrm{l}}_{\alpha_{27}}\right)$ & $\mathrm{E}\left(\overline{\mathrm{l}}_{\alpha_{28}}\right)$ & $\mathrm{E}\left(\overline{\mathrm{l}}_{\alpha_{29}}\right)$ & $\mathrm{E}\left(\overline{\mathrm{l}}_{\alpha_{30}}\right)$ \\
\hline 0.051 & 0.124 & 1.049 & 1.472 & 1.345 & 1.383 & 0.739 & 1.222 & 0.299 & 0.672 \\
\hline $\mathrm{E}\left(\overline{\mathrm{l}}_{\alpha_{31}}\right)$ & $\mathrm{E}\left(\overline{\mathrm{l}}_{\alpha_{32}}\right)$ & $\mathrm{E}\left(\overline{\mathrm{l}}_{\alpha_{33}}\right)$ & $\mathrm{E}\left(\mathrm{l}_{\alpha_{34}}\right)$ & $\mathrm{E}\left(\overline{\mathrm{l}}_{\alpha_{35}}\right)$ & $\mathrm{E}\left(\overline{\mathrm{l}}_{\alpha_{36}}\right)$ & $\mathrm{E}\left(\overline{\mathrm{l}}_{\alpha_{37}}\right)$ & $\mathrm{E}\left(\mathrm{l}_{\alpha_{38}}\right)$ & $\mathrm{E}\left(\overline{\mathrm{l}}_{\alpha_{39}}\right)$ & $\mathrm{E}\left(\overline{\mathrm{l}}_{\alpha_{40}}\right)$ \\
\hline 0.555 & 1.472 & 1.409 & 0.506 & 1.181 & 0.898 & 1.497 & 1.472 & 1.533 & 1.250 \\
\hline $\mathrm{E}\left(\overline{\mathrm{I}}_{\alpha_{41}}\right)$ & $\mathrm{E}\left(\overline{\mathrm{I}}_{\alpha_{42}}\right)$ & $\mathrm{E}\left(\overline{\mathrm{I}}_{\alpha_{43}}\right)$ & $\mathrm{E}\left(\overline{\mathrm{I}}_{\alpha_{44}}\right)$ & $\mathrm{E}\left(\overline{\mathrm{I}}_{\alpha_{45}}\right)$ & $\mathrm{E}\left(\overline{\mathrm{I}}_{\alpha_{46}}\right)$ & $\mathrm{E}\left(\overline{\mathrm{l}}_{\alpha_{47}}\right)$ & $\mathrm{E}\left(\overline{\mathrm{I}}_{\alpha_{48}}\right)$ & $\mathrm{E}\left(\overline{\mathrm{I}}_{\alpha_{49}}\right)$ & $\mathrm{E}\left(\overline{\mathrm{l}}_{\alpha_{50}}\right)$ \\
\hline 1.383 & 1.250 & 1.005 & 1.591 & 1.317 & 0.088 & 1.222 & 2.092 & 1.446 & 0.036 \\
\hline $\mathrm{E}\left(\overline{\mathrm{l}}_{\alpha_{51}}\right)$ & $\mathrm{E}\left(\overline{\mathrm{l}}_{\alpha_{52}}\right)$ & $\mathrm{E}\left(\overline{\mathrm{l}}_{\alpha_{53}}\right)$ & $\mathrm{E}\left(\overline{\mathrm{l}}_{\alpha_{54}}\right)$ & $\mathrm{E}\left(\overline{\mathrm{l}}_{\alpha_{55}}\right)$ & $\mathrm{E}\left(\overline{\mathrm{l}}_{\alpha_{56}}\right)$ & $\mathrm{E}\left(\overline{\mathrm{l}}_{\alpha_{57}}\right)$ & & & \\
\hline 1.049 & 1.317 & 1.079 & 1.005 & 1.290 & 0.073 & 0.706 & & & \\
\hline
\end{tabular}


Step2: The weight of each indicator is obtained via equation (2) and (3), as shown in Table 3.

Table 3

The Weight of 57 Indicators

\begin{tabular}{|c|c|c|c|c|c|c|c|c|c|}
\hline $\mathbf{E}\left(\overline{\mathrm{I}}_{\alpha_{1}}\right)$ & $\mathrm{E}\left(\overline{\mathrm{l}}_{\alpha_{2}}\right)$ & $\mathrm{E}\left(\overline{\mathrm{I}}_{\alpha_{3}}\right)$ & $\mathrm{E}\left(\overline{\mathrm{I}}_{\alpha_{4}}\right)$ & $\mathrm{E}\left(\overline{\mathrm{l}}_{\alpha_{5}}\right)$ & $\mathrm{E}\left(\overline{\mathrm{I}}_{\alpha_{6}}\right)$ & $\mathrm{E}\left(\overline{\mathrm{l}}_{\alpha_{7}}\right)$ & $\mathrm{E}\left(\overline{\mathrm{l}}_{\alpha_{8}}\right)$ & $\mathrm{E}\left(\overline{\mathrm{I}}_{\alpha_{9}}\right)$ & $\mathrm{E}\left(\overline{\mathrm{l}}_{\alpha_{10}}\right)$ \\
\hline 1.079 & 1.005 & 1.018 & 1.151 & 1.122 & 1.049 & 1.222 & 1.049 & 0.088 & 0.051 \\
\hline $\mathrm{E}\left(\overline{\mathrm{I}}_{\alpha_{11}}\right)$ & $\mathrm{E}\left(\overline{\mathrm{I}}_{\alpha_{12}}\right)$ & $\mathrm{E}\left(\overline{\mathrm{I}}_{\alpha_{13}}\right)$ & $\mathrm{E}\left(\overline{\mathrm{I}}_{\alpha_{14}}\right)$ & $\mathrm{E}\left(\overline{\mathrm{I}}_{\alpha_{15}}\right)$ & $\mathrm{E}\left(\overline{\mathrm{I}}_{\alpha_{16}}\right)$ & $\mathrm{E}\left(\overline{\mathrm{I}}_{\alpha_{17}}\right)$ & $\mathrm{E}\left(\overline{\mathrm{l}}_{\alpha_{18}}\right)$ & $\mathrm{E}\left(\overline{\mathrm{l}}_{\alpha_{19}}\right)$ & $\mathrm{E}\left(\overline{\mathrm{l}}_{\alpha_{20}}\right)$ \\
\hline 0.036 & 0.124 & 0.000 & 1.409 & 0.088 & 1.383 & 0.706 & 0.176 & 1.250 & 1.409 \\
\hline $\mathrm{E}\left(\overline{\mathrm{l}}_{\alpha_{21}}\right)$ & $\mathrm{E}\left(\overline{\mathrm{l}}_{\alpha_{22}}\right)$ & $\mathrm{E}\left(\overline{\mathrm{l}}_{\alpha_{23}}\right)$ & $\mathrm{E}\left(\overline{\mathrm{l}}_{\alpha_{24}}\right)$ & $\mathrm{E}\left(\overline{\mathrm{l}}_{\alpha_{25}}\right)$ & $\mathrm{E}\left(\overline{\mathrm{l}}_{\alpha_{26}}\right)$ & $\mathrm{E}\left(\overline{\mathrm{l}}_{\alpha_{27}}\right)$ & $\mathrm{E}\left(\overline{\mathrm{l}}_{\alpha_{28}}\right)$ & $\mathrm{E}\left(\overline{\mathrm{l}}_{\alpha_{29}}\right)$ & $\mathrm{E}\left(\overline{\mathrm{l}}_{\alpha_{30}}\right)$ \\
\hline 0.051 & 0.124 & 1.049 & 1.472 & 1.345 & 1.383 & 0.739 & 1.222 & 0.299 & 0.672 \\
\hline $\mathrm{E}\left(\overline{\mathrm{I}}_{\alpha_{31}}\right)$ & $\mathrm{E}\left(\overline{\mathrm{I}}_{\alpha_{32}}\right)$ & $\mathrm{E}\left(\overline{\mathrm{I}}_{\alpha_{33}}\right)$ & $\mathrm{E}\left(\overline{\mathrm{I}}_{\alpha_{34}}\right)$ & $\mathrm{E}\left(\overline{\mathrm{l}}_{\alpha_{35}}\right)$ & $\mathrm{E}\left(\overline{\mathrm{I}}_{\alpha_{36}}\right)$ & $\mathrm{E}\left(\overline{\mathrm{l}}_{\alpha_{37}}\right)$ & $\mathrm{E}\left(\overline{\mathrm{I}}_{\alpha_{38}}\right)$ & $\mathrm{E}\left(\overline{\mathrm{l}}_{\alpha_{39}}\right)$ & $\mathrm{E}\left(\overline{\mathrm{l}}_{\alpha_{40}}\right)$ \\
\hline 0.555 & 1.472 & 1.409 & 0.506 & 1.181 & 0.898 & 1.497 & 1.472 & 1.533 & 1.250 \\
\hline $\mathrm{E}\left(\overline{\mathrm{I}}_{\alpha_{41}}\right)$ & $\mathrm{E}\left(\overline{\mathrm{I}}_{\alpha_{42}}\right)$ & $\mathrm{E}\left(\overline{\mathrm{I}}_{\alpha_{43}}\right)$ & $\mathrm{E}\left(\overline{\mathrm{I}}_{\alpha_{44}}\right)$ & $\mathrm{E}\left(\overline{\mathrm{I}}_{\alpha_{45}}\right)$ & $\mathrm{E}\left(\overline{\mathrm{l}}_{\alpha_{46}}\right)$ & $\mathrm{E}\left(\overline{\mathrm{l}}_{\alpha_{47}}\right)$ & $\mathrm{E}\left(\overline{\mathrm{l}}_{\alpha_{48}}\right)$ & $\mathrm{E}\left(\overline{\mathrm{l}}_{\alpha_{49}}\right)$ & $\mathrm{E}\left(\overline{\mathrm{l}}_{\alpha_{50}}\right)$ \\
\hline 1.383 & 1.250 & 1.005 & 1.591 & 1.317 & 0.088 & 1.222 & 2.092 & 1.446 & 0.036 \\
\hline $\mathrm{E}\left(\overline{\mathrm{l}}_{\alpha_{51}}\right)$ & $\mathrm{E}\left(\overline{\mathrm{l}}_{\alpha_{52}}\right)$ & $\mathrm{E}\left(\overline{\mathrm{l}}_{\alpha_{53}}\right)$ & $\mathrm{E}\left(\overline{\mathrm{l}}_{\alpha_{54}}\right)$ & $\mathrm{E}\left(\overline{\mathrm{l}}_{\alpha_{55}}\right)$ & $\mathrm{E}\left(\overline{\mathrm{l}}_{\alpha_{56}}\right)$ & $\mathrm{E}\left(\overline{\mathrm{l}}_{\alpha_{57}}\right)$ & & & \\
\hline 1.049 & 1.317 & 1.079 & 1.005 & 1.290 & 0.073 & 0.706 & & & \\
\hline
\end{tabular}

Now, the quality of the $\mathrm{S}$ University's innovation and entrepreneurship education is assessed. Based on the evaluation indicator system proposed in this paper, 12 experts, for example, scholars in this field, relevant leaders, professional teachers, and management personnel from the department of student affairs, the academic office, the admission office, the school youth league committee, and the science industry group, are invited to conduct the evaluation. They score the innovation and entrepreneurship education based on the records and documents, objective data, and their subjective perceptions of this issue. The relationship between the rating and the degree of consent is as follows: -3- strongly disagree, -2-disagree, -1- relatively disagree, 0-fair, 1relatively agree, 2 - agree, 3 - strongly agree. The linguistic information matrix $\bar{L}=\left(\bar{l}_{\alpha_{1}}, \bar{l}_{\alpha_{2}}, \cdots, \bar{l}_{\alpha_{57}}\right)$ is obtained based on the scores.

Step3: The overall evaluation score is obtained via equation (4)

$$
\bar{l}_{\beta}=\bar{l}_{0.992}
$$

The overall score of the quality evaluation of the innovation and entrepreneurship education at the $S$ University is 0.992 , meaning that the overall quality of innovation and entrepreneurship education is good. It also indicates that this university has taken a series of effective and efficient measures to improve the environment of innovation and entrepreneurship education, optimizing the resource allocation of innovation and entrepreneurship education, deploy the resources of innovation and entrepreneurship education and manage the process of innovation and entrepreneurship education. Nevertheless, the score of the first-level, secondlevel, and third -level indicators show that there is still room for improvement. In light of the score of each indicator, the index with the highest score of 2.092 is "Awards for Students in Innovation and Entrepreneurship Contest", suggesting that the S University attaches great importance to the establishment of the practice platforms for innovation and entrepreneurship and to the cultivation of students' innovation and entrepreneurship ability. Likewise, this score reflects that this university has done a good job in encouraging, guiding, and mentoring students to participate in the innovation and entrepreneurship competitions. The indicator with the second highest score of 1.591 is "Introduce Related Regulations on the Flexible Schooling 
System". It is because the S University conducts reform in the academic system, setting a reasonable credit for innovation and entrepreneurship and incorporating it into the credit management. Another indicator with a score higher than 1.5 is "Support Students to Set up Innovation and Entrepreneurship Associations and Clubs", which will boost students' enthusiasm for and dedication to innovation and entrepreneurship.

The distribution of the scores of these indicators is further analyzed. According to Table 2, the scores of the 34 indicators are between 1 and 1.5, indicating that the S University does well in most aspects of the innovation and entrepreneurship education. There are, however, still 20 indicators scoring below 1.0, suggesting that the performance is mediocre. Among them, the indicator with the lowest score, 0 , is "Improve the Benefit Distribution Mechanism for Scientific and Technological Achievements at Universities". It shows that what the $\mathrm{S}$ University needs to improve is the effective transformation of the scientific and technological achievements and the reasonable income distribution mechanism. In terms of several indicators with scores less than 0.1, the score of both "Incorporate the Concept of Innovation and Entrepreneurship Education into the Initial Teaching Training, Curriculum Rotation Training, and Core Member Training" and "The Quantity of the Enterprises Successfully Generated from the Science Park at Universities" is 0.036 , which is below 0.05 . It shows that the $\mathrm{S}$ University neither pays enough attention to the development of the curriculum system regarding the innovation and entrepreneurship education nor fully strengthens the teacher training in this field. Therefore, the concept of the innovation and entrepreneurship education has not been sufficiently integrated with the professional skill curriculum. Meanwhile, the imperfect mechanism of incubation at this university leads to the slow growth and incomplete incubation of the innovative start-ups. In addition, other indicators with scores below 0.1 indicate that the school needs to increase inputs in the following aspects, for instance, providing more financial support for the innovation enterprises, promoting the concept and facilitating the practice of the entrepreneurship education, and hiring talents from all walks of life to serve as teachers or tutors of the innovation and entrepreneurship courses. Then, the overall quality of the innovation and entrepreneurship education at this university will be enhanced.

\section{Conclusion}

There is an urgent need for the Chinese government to implement an innovation-driven development strategy and to enhance the economic efficiency. In response to this need, the reform of innovation and entrepreneurship education at colleges and universities should be deepened, which will likewise facilitate the comprehensive reform of higher education, thereby assisting university graduates in finding better-paid employment or starting a new business. Although various colleges and universities in China have vigorously promoted the innovation and entrepreneurship education reform in recent years, the actual implementation varies. To further implement the "Opinions on Implementation" and to facilitate a better, faster, and more benign development of the innovation and entrepreneurship education at colleges and universities, establishing an accurate and effective quality evaluation system and creating suitable evaluation methods have become an urgent task for the academia. In this context, this paper, after reviewing the literature, uses the Delphi method to establish the logic hierarchy system for evaluating the quality of the innovation and entrepreneurship education at colleges and universities. It consists of four first-level indicators (i.e. the environment, resources, 
processes, and achievements of the innovation and entrepreneurship education), 12 second-level, and 57 thirdlevel indicators. Secondly, the paper selects the linguistic operator as the research method after comparing the advantages and disadvantages of each evaluation method and taking into account the characteristics of the quality assessment of the innovation and entrepreneurship education. Then, by introducing the basic theory of the linguistic operator, an evaluation model is constructed. In this model, a host of evaluators evaluate each indicator, obtaining the linguistic information. Then, the paper converts the linguistic information into a linguistic information matrix, thereby calculating the score of each indicator via the standard deviation method and the related linguistic operator algorithm. Next, the overall score of the quality of the innovation and entrepreneurship education is obtained via the LWAA operator. Eventually, a case study of the S University is presented; the detailed evaluation processes of this approach are demonstrated, and suggestions are put forward for the S University to enhance the overall quality of innovation and entrepreneurship education. The statistical results demonstrate the applicability and practicability of the proposed model in this paper.

\section{References}

Aggarwal, M. (2017). Adaptive linguistic weighted aggregation operators for multi-criteria decision making. Applied Soft Computing, 58, 690-699. http://dx.doi.org/10.1016/j.asoc.2017.04.063

Betoret, F. D., \& Tomás, A. D. (2003). Evaluation of the university teaching/learning process for the improvement of quality in higher education. Assessment \& Evaluation in Higher Education, 28(2): 165178. http://dx.doi.org/10.1080/02602930301672

Coffey, M., \& Gibbs, G. (2001). The evaluation of the student evaluation of educational quality questionnaire (SEEQ) in UK higher education. Assessment \& Evaluation in Higher Education, 26(1): 89-93. http://dx.doi.org/10.1080/02602930020022318

Dalkey, N., \& Helmer, O. (1963). An experimental application of the Delphi method to the use of experts. Management Science, 9(3): 458-467. http://dx.doi.org/10.1287/mnsc.9.3.458

Denekens, J. (2007). Student evaluation of teaching quality in higher education: development of an instrument based on 10 Likert-scales. Assessment \& Evaluation in Higher Education, 32(6): 667-679. http://dx.doi.org/10.1080/02602930601117191

Feng, Y. F., \& Tong, X. L. (2013). Quality Evaluation Model and Method of Innovation and Entrepreneurship Education in Research-oriented Universities [J]. Journal of Huazhong Agricultural University (Social Sciences Edition), 1, 122-128.

Feng, Y. F., \& Tong X. L. (2013). University innovation and entrepreneurship studies in educational evaluation based on fuzzy analytic hierarchy process. Journal of North China Electric Power University, (02), 137140. http://dx.doi.org/10.3969/j.issn.1008-2603.2013.02.024

Fouskakis, D., Petrakos, G., \& Vavouras, I. (2016). A Bayesian hierarchical model for comparative evaluation of teaching quality indicators in higher education. Journal of Applied Statistics, 43(1): 195-211. http://dx.doi.org/10.1080/02664763.2015.1054793 
Gao, K., \& Hua, J. C. (2015). Evaluation of innovation and entrepreneurship education in colleges and universities based on improved AHP method. Modern Education Management, (04), 61-64. http://dx.doi.org/10.3969/j.issn.1674-5485.2015.04.011

Hallinger, P. (2010). Using faculty evaluation to improve teaching quality: A longitudinal case study of higher education in Southeast Asia. Educational Assessment Evaluation \& Accountability, 22(4): 253-274. http://dx.doi.org/10.1007/s11092-010-9108-9

He, Y., Guo, H., Jin, M., \& Ren, P. (2016). A linguistic entropy weight method and its application in linguistic multi-attribute group decision making. Nonlinear Bynamics, 84(1), 399-404. http://dx.doi.org/10.1007/s11071-015-2595-y

http://dx.doi.org/10.3969/j.issn.1674-893X.2010.06.001

Hu, M., Ren, P., Jin, M., Lan, J., \& Luo, Y. (2013). A satisfaction evaluation method for scenic spot based on linguistic weighted arithmetic average operator. Applied Mathematics \& Information Sciences, 7(6), 22592270. http://dx.doi.org/10.12785/amis/070616

Jiang D. Q. (2015). The Research on the construction of quality evaluation system for the innovation and entrepreneurship education in university. Journal of Innovation and Enterprise Education. 6(06), 1-4. http://dx.doi.org/10.3969/j.issn.1674-893X.2015.06.001

Liu, Q. (2016). Design and practice of quality evaluation system of innovation and entrepreneurship education. Journal of Nanchang Institute of Technology. 35(02):5-11. http://dx.doi.org/10.3969/j.issn.10064869.2016.02.002

Liu, Z. Z., Zhang, Y., \& Zhang, G. (2009). Research on the innovation and start-up education assessment system at sport colleges. Journal of Nanjing Institute of Physical Education, 23(02): 99-103. http://dx.doi.org/10.3969/j.issn.1008-1909.2009.02.024

Okoli, C., \& Pawlowski, S. D. (2004). The Delphi method as a research tool: an example, design considerations and applications. Information \& management. 42(1): 15-29. http://dx.doi.org/10.1016/j.im.2003.11.002

Romainville, M. (1999). Quality evaluation of teaching in higher education. Higher Education in Europe. 24(3), 415-424. http://dx.doi.org/10.1080/0379772990240309

Stufflebeam, D. (2001). Evaluation models. New Directions for Evaluation, 2001(89), 7-98. http://dx.doi.org/10.1002/ev.3

Stufflebeam, D. L. (2003). The CIPP model for evaluation. In International handbook of educational evaluation (pp. 31-62). Springer, Dordrecht.

Stufflebeam, D. L., \& Zhang, G. (2017). The CIPP evaluation model: How to evaluate for improvement and accountability. Guilford Publications.

Stufflebeam, D. L., \& Shinkfield, A. J. (2007). Evaluation theory, models, and applications. Jossey-Bass, An Imprint of Wiley.

Tsinidou, M., Gerogiannis, V., \& Fitsilis, P. (2010). Evaluation of the factors that determine quality in higher education: An empirical study. Quality Assurance in Education: An International Perspective, 18(3): $227-$ 244. http://dx.doi.org/10.1108/09684881011058669

Wu, Z., Chen, Y. (2007). The maximizing deviation method for group multiple attribute decision making under linguistic environment. Fuzzy Sets and Systems, 158(14): 1608-1617. http://dx.doi.org/10.1016/j.fss.2007.01.013 
Yuan, Zhang, Wang, Li / A Research on the Quality Evaluation of the Innovation and Entrepreneurship Education at...

Xie, Z. Y., \& Liu, W. A. (2010). Research on quality evaluation system of entrepreneurship education in colleges and universities. Journal of Innovation and Enterprise Education. 1(06):3-13.

Xu, Y., Bai, H. (2014). The Research on Quality Evaluation of Innovation and Enterprise Education at Universities. Journal of Innovation and Enterprise Education, 5(02), 29-33. http://dx.doi.org/10.3969/j.issn.1674-893X.2014.02.010

Xu, Y., Merigó, J. M., \& Wang, H. (2012). Linguistic power aggregation operators and their application to multiple attribute group decision making. Applied Mathematical Modelling, 36(11): 5427-5444. http://dx.doi.org/10.1016/j.apm.2011.12.002 